\title{
ІСТОРІя подІлля
}

УДК 94(477.43/44) «1920-1923»

DOI: https://doi.org/10.31652/2411-2143-2020-32-25-31

\author{
Михайло Панасюк \\ Вінницький державний педагогічний університет імені Михайла Коцюбинського \\ аспірант (Україна) \\ e-mail: pm.vin@ukr.net \\ ORCID: https://orcid.org/0000-0003-3497-1270
}

\section{Використання радянською владою подільського учительства в антирелігійній пропаганді на початку 1920-х рр.}

\begin{abstract}
Анотація. Метою статmі є висвітлення прагнень представників радянської влади використати подільських учителів в антирелігійній пропаганді на початку 1920-хрр.. Методологія дослідження базується на принципах історизму, науковості, об'єктивності, системності, соціального підходу, на використанні загальнонаукових (описового, узагальнення, систематизації, аналізу) та спеціально-історичних (історико-порівняльний, структурно-фуннкціональний, конкретно-соціологічний) методів. Наукова новизна полягає в тому, що на основі архівних матеріалів визначено місце та роль окремої категорії населення радянського суспільства - учителів в антирелігійній кампанії початку 20-х рр.. XX cm. на Поділлі, розкриваються причини, що змушували комуністичне керівництво активно залучати педагогічні кадри в протидії церковному руху. Висновки. Незважаючи на посилення антицерковної кампанії, насадження атеїзму на території Поділля відбувається піднесення активності вірян. Яскравим проявом релігійності населення була поява так званих чудес та масове поклоніння місиям, де вони виникали. Відомими чудесами в той час були: Калинівський хрест, явлення Божої Матері в Йосафратовій долині, масове оновлення ікон, поява хрестів та інші. Відомості про чудеса швидко розповсюджувались на території краю, набуло поширення паломництво до місць появи чудес. Активізація церковного руху та формування відповідного настрою серед населення всіляко непокоїло радянське керівництво. Однією із форм протидії цьому явищу з боку держави було створення спеціальних комісій, що мали на меті розвінчування фрактів чудес. До роботи в комісіях активно залучали вчителів Подільського краю, які проводили роз'яснювальну роботу, виступали на різноманітних зібраннях, гуртках, конфреренціях. Ідеологічно свідомі педагоги готували доповіді про походження Землі, появу людини, виникнення релігій. Вчителі-фрізики та хіміки залучались до спростування фракту чудес шляхом проведення досліду. Робота подільського вчительства стала дієвою підтримкою партійних органів у боротьбі з релігійним рухом на початку 1920-х рр..
\end{abstract}

Ключові слова: антицерковна політика, вчителі, партійне керівництво, релігійний рух, релігійні чудеса, спеціальні комісії.

Постановка проблеми. Відносини між державними органами та церковними структурами мають важливе значення для розвитку суспільства. В сучасних умовах в Україні посилюється релігійна напруга, загострюються протиріччя між православними конфесіями. Налагодження діалогу між державою та церковними організаціями, між різними релігійними об'єднаннями є вкрай необхідним для встановлення миру та спокою в державі. Тому взаємовідносини держави та церкви не втрачають актуальності. Яскравим прикладом у цьому $є$ релігійне протистояння населення Подільського краю антицерковному наступу на початку 20x pp.. XX cт. Активність вірян набувала різних фрорм. Одним із проявів такої активності було поклоніння місцям, де виникали так звані чудеса. Для боротьби з ними місцева влада почала залучати не лише партійних функціонерів, а й педагогічні кадри.

Аналіз джерел та останніх досліджень. Релігійні рухи населення краю у зазначений період привертали увагу багатьох вітчизняних дослідників. Перші публікації з'явились у 20-х рр.. минулого століття, тобто підчас появи чудес, що зумовили масовий церковний рух. Варто згадати працю Никанора Дмитрука «Про чудеса на Україні року 1923-го» [Дмитрук, 1925], Олени Пчілки «Українські народні легенди останнього часу» [Пчілка, 1925], Василя Кравченка «Псалми, що в 1923-24 рр. співали прочани під час подорожувань до різних чудес» [Кравченко, 1927].

Посилюється інтерес до цієї теми наприкінці 90-х рр.. XX ст. та на початку 2000-х рр.. С. І. Дровозюк приділив увагу питанню висвітлення православних чудес в історичній літературі 3 часу їх появи до кінця 90-х рр.. XX ст. [Дровозюк, 2002]. Релігійні рухи досліджували: К. В. Завальнюк, В.М.Дяків, Л.Л.Бабенко, М.П.Олійник, О.М.Галамай, О.О.Стадник, Н. П. Кузьмінець. Володимир Дяків характеризує в яких умовах проявлялась народна 
релігійність, приділяє увагу конкретним чудесам на території сучасної Вінниччини (Калинівський хрест, явлення Божої Матері в Йосафатовій долині), дослідник вважає, що активність вірян була своєрідною реакцією на агресивний наступ войовничого більшовицького безбожництва [Дяків, 2010]. Людмила Бабенко відзначає масштаби наступу державних каральних органів на таке населення в межах республіки, вона вважає, що найбільший рух вірян відбувався на теренах Поділля, питання боротьби з «чудесними явищами» в цьому регіоні неодноразово включалось до порядку денного засідань не лише окружних, губернських паркомітетів, а й засідань політбюро ЦК КП(б)У [Бабенко, 2013]. Олена Галамай неодноразово висвітлювала у своїх публікаціях поширення чудес на території Вінниччини, зокрема приділила увагу характеру релігійних чудес у Вінницькому, Тульчинському, Могилів-Подільському округах [Галамай, 2002]. Микола Олійник вивчав питання появи чудес по всій території Подільського краю, в межах сучасних Хмельницької та Вінницької областей, вказує на позицію ЦК РКП(б), Подільського губкому КП(б)У в релігійному питанні в зв'язку з подіями, що відбувались у 1923 році на території краю [Олійник, 2013]. Олена Стадник та Наталія Кузьмінець розглядають поширення православних чудес як невід'ємний фактор повсякденного життя подільського селянства [Стадник О. \& Кузьмінець Н. 2020].

Так, народний рух подолян, пов'язаний з появою чудес, достатньо висвітлений в історичній літературі, але участь учителів в антирелігійній кампанії не досліджувалась, автор вважає необхідним приділити увагу висвітленню саме цього аспекту.

Метою статті $€$ розкриття ролі педагогічних працівників у протидії релігійному руху на Поділлі на початку 1920-х рр.

Виклад основного матеріалу. Релігійні рухи мали місце в багатьох регіонах України, вони були однією із форм протидії антицерковній діяльності радянської влади. Подільський край став одним із головних центрів релігійного протистояння, а найяскравіші події розвивалися в $1923 \mathrm{p}$.

Проаналізувавши ряд документів, зокрема ті, що стосуються діяльності окружних партійних комітетів на Вінниччині, можна визначити характер появи чудес у краї, особливості їх поширення, фрорми і методи боротьби з ними партійних та державних органів влади, роль учителів у цьому процесі.

У церковній практиці оновлення ікон, поява на них миру, явлення святих, Божої Матері $€$ невід'ємною частиною духовного життя. Віряни всіляко шанували місця та предмети, де вони проявлялись. У 1923 р. явлення чудес стали особливо частим, поклоніння їм збирало велику кількість людей. Рух навколо чудес відбувався в умовах посилення антирелігійної пропаганди, боротьби з церковними структурами.

Протягом 1923 року в донесеннях Вінницького та Могилів-Подільського окружних комітетів КП(б)У фрігурувала інфрормація про появу чудес. Протидія їм зайняла одне з головних місць у діяльності партійних органів влади поряд з такими питаннями як організація посівної кампанії, сплата продподатку, боротьба з бандитизмом та інше. У черговому донесенні Вінокркому в серпні 1923 р. було вказано, що чудеса, котрі появлялись у липні, не дивлячись на те, що Окружний виконавчий комітет своєчасно прийняв відповідні заходи для роз'яснення населенню їх сутті, продовжують появлятись, і до останнього часу виникають у фоормі оновлених образів, хрестиків та інших речей релігійного культу [ДАВіО. Ф.П-29. Оп.1. Спр.17. Арк. 33]. Вінницький окружком свідчив, що чудеса і оновлення в серпні 1923 р. охопила весь округ.

Могилів-Подільський окружний комітет КП(б)У визнав головними формами активності вірян ходіння до Йосафатової долини, ставлення хрестів та масове оновлення ікон [ДАВіО. Ф.П-1. Оп.1. Спр.853. Арк.3]. Гайсинський окружний комітет у вересні 1923 р. свідчив, що чудеса (оновлення ікон) офіційно зареєстровані в трьох місцях, але широкого розповсюдження вони не мали [ДАВіО. Ф.П-30. Оп.1 Спр. 5. Арк.97]. У жовтні 1923 р. у Вінницькому окрузі фріксується нова хвиля чудес, але вже не у формі оновлення ікон, а у появі так би мовити без всякої сторонньої допомоги хрестів у полі.

У листопаді 1923 р. секретар Вінокркому визначив найбільші релігійні рухи: паломництво до Калинівського хреста, побудова хрестів і ходіння з ними до так званої «Сафратової долини» у Могилівському окрузі [ДАВіО. Ф.П-29. Оп.1. Спр.717. Арк.105].

Так, можна зробити висновок, що найбільш розповсюдженими стали такі явища духовного життя краю: Калинівський хрест та народні рухи пов'язані $з$ ним; Голичинське чудо або явлення Божої Матері в Йосафатовій долині; ставлення хрестів; оновлення ікон.

Партійні органи детально вивчали характер чудес та шляхи протидії їх поширенню серед населення. Тривало обговорення цієї проблеми, висловлювались пропозиції щодо боротьби з таким явищем. На той час керівництво краю не могло застосувати відкрито репресивні заходи, тому протидія набувала різних форм.

Поширення релігійного руху класифікувались представниками партійних осередків як посилення куркульського елементу на селі, оскільки на робітників чудеса не мали такого впливу, 
як серед сільської людності [ДАВіО. Ф.П.-29. Оп.1. Спр.1. Арк.15]. Для створення хрестів потрібен матеріал, тому комуністичні керівники намагались пов'язати будівництво хрестів 3 крадіжкою лісу, селянин міг бути покараний не за паломництво зі хрестом, а за несанкціоновану вирубку лісу.

Агітаційна робота окружкомів торкалася проблем конокрадства, поширення інфекційних хвороб, селян застерігали від участі у масових рухах через можливе викрадення коней в дорозі, особливо вночі. Народні ходіння продовжувались і в жовтні, і в листопаді 1923 р., часто селяни ходили босими за браком взуття. Окружкоми давали вказівку провести роз'яснювальну роботу про захворювання, можливе поширення епідемії і т. п., цим самим відвернути частину населення від участі в релігійному русі [ДАВіО. Ф.П-1. Оп.1. Спр.17. Арк.104].

Рух вірян партійні діячі пов'язували з внутрішньою та закордонною «контрреволюцією», залишками білого руху. Відвернути селян від хресних ходів повинна була роз'яснювальна робота про порушення громадського порядку, бандитизм, можливе викрадення майна, що участь у паломництві відвертає від роботи на землі, сприяє розоренню.

Подібні дії не давали вагомого результату, тому приймались рішення про створення спеціальних комісій. Завданням комісії було спростування факту чудес, науково, з допомогою досліду, пояснити ті чи інші явища природнього процесу. Склад комісій був різним, але важливу роль у них відводили учителям. Спочатку створювались комісії з державних та партійних представників. Часто це були так звані трійки: секретар парткому, представник виконкому та представник ДПУ [ДАВіО. Ф.П-1. Оп.1. Спр.853. с.12].

Далі створювали комісії з інтелігенції, до яких входили учителі, лікарі, агрономи, хіміки, священники. 3 наукового погляду, а також з політичного селянству доводили неможливість появи чудес. Члени комісії отримували чіткі вказівки (під особисту відповідальність кожного) про те, як вести себе серед селян, скільки часу перебувати на місці, на які теми повинні бути підготовлені доповіді [ДАВО. Ф.П-1. Опис.1. Спр.853. Арк.13].

Цікавим $€$ фракт перебування в комісії священника, становище якого було вкрай складним. 3 одного боку, служителі церкви всіляко підтримували прояви релігійності населення, з іншої сторони - церковна свідомість сприймала частину чудес як фракти, в яких не сумнівались. Але багато «чудес» для священника були просто народною фантазією, вигаданим явищем. Особливо масово поширювались явища оновлення ікон та поява на них миру. У церковному житті приклади оновлення стосувались переважно давніх ікон, зображення на яких знову ставало чітким без сторонньої допомоги. Масовість оновлення церковних речей переходило тоді всі межі. Священники не визнавали багатьох чудес, і розуміючи реальний стан речей, повинні були говорити правду. Потрібно враховувати, що служителі церкви першими могли бути притягнуті до відповідальності за «контрреволюційні» наміри. Слово духовного пастиря та сам факт його присутності в комісії здійснював відповідний вплив на селянські настрої, священники в більшості визнавали ті чудеса, які для вірян були очевидними. Стосовно оновлення ікон на дому, то позиція отців перед представниками партійних органів була не однозначною: одні вірили в чудеса, інші - ні. Архівні матеріали подають нам дані про масовість оновлення ікон. У Мурафському районі, Могилів-Подільський округ оновлено 110 ікон, у Станіславському районі, Могилів-Подільський округ - 64 ікони, в с. Хренівка Копайгородського району обновилось 12 ікон [ДАВіО. Ф.П-1. Оп.1 Спр.900. Арк.6].

У Вінницькому окрузі обновилось: у Калинівському районі - 18 ікон, в Мало-кутищенськму - 3 ікони, Пиківському - 10 ікон, Хмільницькому - одна, Літинському - 7, Прилуцькому одна [ДАВіО. Ф.П-29. Оп.1. Спр.17. Арк.33].

Створення комісій із представників інтелігенції та учителів були до певної міри вимушеним. Керівництво не могло застосувати відкрито репресивні заходи, в суспільстві виникав відповідний резонанс, арешти не мали результатів, тому їх застосовували обережно, давались чіткі вказівки про тактичний підхід до мас.

Місцеві партійні функціонери, сільські, районні були доволі слабкими в адміністративному, ідеологічному, науковому плані, виникала необхідність у їх посиленні. Великі надії покладались на КСМ. У ряді донесень говорилось, що молодь байдужа до релігійних рухів. Але ходіння до Калинівського хреста та Йософатової долини свідчило про протилежне. Комсомольці не могли виконати покладене на них доручення. Вони часто вели себе не тактовно, ображали селян і не могли запропонувати ніяких серйозних аргументів проти релігії.

У цих умовах комісії стали дієвим інструментом для боротьби з народно-релігійним рухом. Для більшого авторитету склад комісій носив переважно безпартійний характер. Якщо хтось з членів комісій володів українською мовою, він обов'язково повинен був читати доповіді українською [ДАВіО. Ф.П.-1. Оп.1. Спр.900. Арк.3].

У деяких місцях вчителі проявляли озлобленість на духовенство, чим вирішили скористатись партійні діячі [ДАВіО. Ф.П-1. Оп.1. Спр.900. Арк.6]. Відносини між духовенством та учителями погіршувались. Вчитель ставав виразником ідей, що пропагувала радянська влада, 
включаючи релігійні питання. Духовний пастир до певної міри залишався конкурентом у боротьбі за свідомість громадян, тому священників часто утискували, їх позбавляли права голосу на рівні з колишніми представниками царського режиму, учасниками білогвардійських загонів. Священників, що жили в церковних хатах виселяли із помешкання, а приміщення забирали під школи [ДАВіО. Ф.Р-489. Оп.1. Спр.847. Арк.151].

Участь інтелігенції в комісіях була і добровільною, і примусовою. На вчителів покладалися великі надії. Вінницький партійний діяч Савельєв 3 серпня 1923 р. на засіданні Пленуму Вінокркому доповів про роботу серед вчителів, запропонував визнати ії першочерговою i важливою, вказував на необхідність створення з учителів працівників політично зрілих, свідомих, яких можна було б використати як передових комуністичних педагогічних кадрів школи та суспільства. Надавати цьому всіляку підтримку. До шкільних рад запропонувати представника місцевого партійного осередку. Педагогічні об'єднання повинні тісно співпрацювати з місцевими партійними організаціями. Вчителів необхідно використовувати для ведення антирелігійної пропаганди на селі, залучати їх до читання лекцій в сільбудинках, хатах-читальнях по природничим науковим питанням [ДАВіО. Ф.П-29. Оп.1. Спр.4. Арк.8].

Члени комісії повинні були вести роз'яснювальну роботу, фріксувати випадки появи чудес, по можливості, на очах населення самостійно проводити власні «чудеса», наприклад, доводити, що зміна кольору на церковних речах зумовлена фрізичними властивостями предмету. Один із членів комісії, як правило, хімік, повинен був взяти ікону і продемонструвати які зміни відбуваються під дією окремих речовин, вологості, повітря. Організовувались збори та конференції, які мали бути безпартійними, в такому випадку вони мали більший вплив на населення. Могилів-Подільський окрпарком дав таку вказівку: «В справу розвінчування явища оновлення ікон втягувати в першу чергу безпартійні наукові кадри, представлені в комісіях» [ДАВіО. Ф.П-1. Оп.1. Спр.900. Арк.3].

Представник місцевої партійної організації був, звичайно, присутнім на зборах. В його промовах народно-релігійні рухи класифрікувались як спроба контрреволюції використати вірування темних мас населення проти радянської влади. Але всі доповіді наукового чи просвітницького характеру представляли вчителі, лікарі, агрономи. Теми доповідей, порядок виступів обумовлювався окрпаркомом. Могилів-Подільський окружний партійний комітет на безпартійну конференцію затвердив наступні теми виступів: 1. Про походження землі (доповідач - вчитель); 2. Про появу життя на землі, тварин, людини (знахарство, медицина та релігія), (доповідач - лікар); 3. Про походження релігії (вірування древніх слов'ян), (доповідач - вчитель); 4. Погляди церкви на оновлення ікон (доповідач - священник); 5. Про атмосферу, клімат та їх вплив на сільське господарство (грім, блискавка, сонце, засуха), (доповідач - агроном); 6. Погляди науки хімії на оновлення ікон як справу рук людських, а не Божого чуда (доповідач хімік) [ДАВіО. Ф.П-1. Оп.1. Спр.900. Арк.2].

Уповноважений окрпаркому перебував на місці чуда не менше трьох днів, виїжджати 3 району дозволялося, якщо проведена робота досягла результатів серед населення. Після чого складався детальний звіт про проведену кампанію, настрої мас, політичну ситуацію та результати роботи.

Просвіщали не лише селянство. Вінокрпарком виніс резолюцію за підсумками районної партконференції - місцевим органам влади приділяти максимум уваги виховній роботі серед різних соціальних груп шляхом читання лекцій про будову землі та природознавство, для чого залучити всі культурні сили на селі [ДАВіО. Ф.П-29. Опис.1. Спр.1. Арк.27].

3 метою посилення антирелігійної пропаганди при сільбудинках створювали наукові гуртки, а лекції там читали учителі. Якщо комісії складались лише з місцевих комуністів, то вони обмежувались фрактом фіксування чудес. Не проводилась потужна пропагандистська та науково-просвітницька робота. До чудес приверталась ще більша увага населення, робота комісій в такому випадку давала протилежні результати.

Представники місцевих органів КП(б)У неодноразово висловлювались з питань появи чудес, їх масового розповсюдження. Комуністичні керівники вважали, що для унеможливлення появи чудес необхідно посилити роботу в клубах, сільських будинках, заповнити духовну сторону людей науковою та антирелігійною інформацією, літературою, відпочинком, використовувати для цього не лише сільську, а й міську інтелігенцію [ДАВіО. Ф.П-1. Оп.1. Спр.900. Арк.7].

У розповсюдженні інформації про чудеса визнали винними частину районних керівників, які, на думку діячів окружної влади, не відповідали вимогам часу і не володіли ситуацією, в якій опинились, пропонували їх змінити.

Причинами поширення релігійного руху вважали недостатність антирелігійної пропаганди та слабкість політпрацівників, що необхідно було виправити, організувавши курси по підвищенню їх ідейного та наукового рівня. Також було відмічено, що чудес більше там, де нема учителів або вони нічого не варті. Загалом, роль учительства в протидії різних явищ духовного 
життя була визнана важливою. Робота педагогічних працівників найкраще оцінювалась партійним керівництвом, особливо відзначались їх доповіді на конфреренціях. Виступи вчителів стали суттєвою допомогою комуністичним працівникам [ДАВіО. Ф.П-1. Оп.1. Спр.900. Арк.7].

Важливість діяльності вчителя для партійного керівництва проявилась у питаннях своєчасного отримання педагогами заробітної плати. Наприклад, Могилів-Подільський окружком КП(б)У всім місцевим осередкам доніс інфрормацію, що фрінансування шкільної праці за залишковим принципом недопустиме, виплата зарплати вчителю $\epsilon$ питанням політичної значимості, вимагав негайно прийняти рішучі заходи в цьому питанні та задовольнити повністю потреби у фінансуванні шкіл та шкільних працівників [ДАВіО. Ф.П-1. Оп.1. Спр.898. Арк.106].

Висновки. Так, на початку 1920-х р. на території Поділля мали місце широкі народні рухи, пов'язані з появою т. зв. релігійних чудес. Активізація церковного руху та формування відповідного настрою серед населення всіляко непокоїло радянське керівництво. Найбільш масовими акціями серед вірян були: паломництво до Калинівського хреста та Йосафатової долини, ставлення хрестів, шанування оновлених ікон. Для боротьби з цими явищами місцеві органи КП(б)У активно залучали інтелігенцію та вчительство краю.

Учителі брали участь у роботі комісій з ліквідації чудес, наукових гуртках, сільських будинках, виступали на з"їздах та конференціях з антирелігійними доповідями.

Партійне керівництво визнало роботу учителів важливою, корисною і такою, що відповідала вимогам часу. Діяльність учителів стала значною підтримкою для партійних органів в питаннях протидії релігійному руху та посиленні антирелігійної пропаганди на території краю.

Подяка. Висловлюємо щиру вдячність усім членам редколегії журналу за консультації, надані під час підготовки статті до друку.

Фінансування. Автор не отримав фрінансової підтримки для дослідження, авторства та публікації цієї статті.

\section{Джерела та література:}

Бабенко, Л. Л. (2013). Взаємодія партійно-радянських органів та місцевих апаратів держбезпеки в боротьбі 3 «релігійними чудесами» (1920-ті-1940ві рр.). 3 архівів ВУЧК-ГПУ-НКВДКГБ, 1, 327-350.

Галамай, О. М. (2002). Релігійні чудеса на Вінниччині. Вінниччина: історія та сучасність. Вінниця, 50-54.

ДАВіО - Державний архів Вінницької області.

Дмитрук, Н. (1925). Про чудеса на Україні року 1923-го. Етнографрічний вісник, 1, 50-65.

Дровозюк, С.І. (2002) Масовий релігійний рух в Україні у 20-х pp. XX ст.: історіографрія проблеми. Наукові записки Вінницького державного педагогічного університету імені Михайла Коцюбинського. Серія: Історія, 4, 247-253.

Дровозюк, С. І. (2005.) Національно-культурне та духовне життя українського селянства у 20 - 30-х рр. XX століття: історичний нарис. Вінниця, 364 с.

Дяків, В.М. (2010). Прояви релігійності українців в умовах більшовицької окупації початку 1920-х років. Вісник Львівського університету. Серія: Філологія, 43, 169-180.

Завальнюк, К., Стецюк, Т. (2007) Релігійні “чудеса" на Поділлі (20-ті роки XX століття). Ред. колегія: 3. Білик, Я. Дашкевич, Л. Моравська, Історія релігій в Украӥні. Науковий щорічник, (409419). Львів: Видавництво Львівського музею історії релігії «Логос».

Кравченко, В. (1927) «Псальми», що в 1923 - 24 рр. співали прочани під час подорожувань до різних чудес. Етнографрічний вісник, 4, 71-78.

Олійник, М. П. (2013). Прояви чудес та оновлення ікон на Поділлі в 1923 р. та боротьба влади 3 цим явищем. Освіта, наука і культура на Поділлі, (20), 509-519.

Панасюк, М. П. (2019). Релігійна творчість подолян в 1920-х рр.. Наукові записки Тернопільського національного педагогічного університету імені Володимира Гнатюка. Серія: Історія, 2, 123-127.

Пчілка, О. (1925). Українські народні легенди останнього часу. Етнографрічний вісник. 1, 41-49.

Стадник, О. \& Кузьмінець, Н. (2020). Релігійне життя подільського села у вимірах радянської повсякденності 20-х рр.. XX ст. Наукові записки Вінницького державного педагогічного університету імені Михайла Коцюбинського. Серія: Історія, 31, 79-87. DOI: https://doi.org/10.31652/2411-2143-2019-31-79-87 


\title{
Михаил Панасюк
}

Винницкий государственный педагогический университет имени Михаила Коцюбинського аспирант (Украина)

\section{Использование советской властью подольского учительства в антирелигиозной пропаганде в начале 1920-х гr.}

\begin{abstract}
Аннотация. Целью статьи является освещение стремлений представителей советской власти использовать подольских учителей в антирелигиозной пропаганде в начале 1920-х ге.. Методология исследования базируется на принципах историзма, научности, объективности, системности, социального подхода, на использовании общенаучных (описательного, обобщения, систематизации, анализа) и специально исторических (историко-сравнительный, структурно функциональный, конкретно социологический) методов. Научная новизна заключается в том, что на основе архивных материалов определенно место и роль отдельной категории населения советского общества - учителей в антирелигиозной кампании начала 20-х г2.. XX ст. на Подолии, раскрываются причины, которые вынуждали коммунистическое руководство активно привлекать педагогические кадры в противодействии церковному движению. Выводы. Невзирая на усиление антицерковной кампании, насаждения атеизма, на территории Подолья происходит подъем активности верующих. Ярким проявлением религиозности населения было появление так называемых чудес и массовое поклонение местам, где они возникали. Известными чудесами в то время были: Калиновский крест, явление Божьей Матери в Йосафратовой долине, массовое обновление икон, появление крестов и другое. Сведения о чудесах быстро распространялись на территории края, множились паломничества к местам появления чудес. Активизация церковного движения и формирование соответствующего настроения среди населения всячески беспокоило советское руководство. Одной из форм противодействия этому явлению со стороны государства было создание специальных комиссий, что имели целью развенчивания фрактов чудес. До работы в комиссиях активно привлекали учителей Подольского края, которые проводили разъяснительную работу, выступали на разнообразных собраниях, кружках, конференциях. Идеологически сознательные педагоги готовили доклады о происхождении Земли, появлении человека, возникновения религий. Учителя-физики и химики привлекались к опровержению фракта чудес путем проведения опыта. Работа подольского учительства стала действенной поддержкой партийных органов в борьбе с религиозным движением в начале 1920-х г2..
\end{abstract}

Ключевые слова: религиозное движение, партийное руководство, антицерковная политика, учителя, специальные комиссии, религиозные чудеса.

\author{
Mykhailo P. Panasiuk \\ Vinnytsia Mykhailo Kotsiubynskyi State Pedagogical University \\ Postgraduate Student (Ukraine)
}

\section{The exploitation of teaching in Podillia by the Soviet authorities in the anti-religious propaganda in the early 1920s.}

\begin{abstract}
The purpose of the article is to highlight the aspirations of the Soviet authorities to explore teachers in Podillia in the anti-religious propaganda in the early 1920's. The methodology of the study is based on the principles of historicism, science, objectivity, systematic, social approach, the use of the general methods (description, generalization, systematization, analysis) and the specialhistorical ones (historical-comparative, structural-functional, concrete-sociological). The scientific novelty is that the place and the role of a separate category of the population of the Soviet society were determined on the basis of archival materials. They were educators in the anti-religious campaign of the early 20s of the 20th century in Podillia. The reasons for forcing the Communist leadership to active educators engaging in opposing the church movement are revealed. Conclusions. Despite the anti-church campaign intensification, the establishment of atheism on the territory of Podillia the believers activity raises. A striking manifestation of the population devoutness was the appearance of the so-called miracles and mass worship to the places where they had occured. The well-known miracles of that time were: the Kalyniv Cross, the appearance of the God's Mother in the Jehoshaphat valley, the mass renewal of icons, the appearance of crosses and others. The miracles spread rapidly throughout the region, and the pilgrimage spread to the places where the miracles had occurred. The intensification of the church movement and the formation of an appropriate mood among the population disturbed the Soviet authorities greatly. One form of the state
\end{abstract}


confrontation to this phenomenon was the creation of special commissions that had to disclose the facts of the miracles. The educators of Podillia were actively enlisted in the commissions work, they performed explanatory work, participated in various meetings, societies, conferences. Ideologically conscious teachers prepared reports about the Earth origin, the appearance of a man, the emergence of religions. The teachers of Physics and Chemistry were involved in the impugnment of the miracles existence through performing the experiments. The work of Podillia's educators became an effective support for the party organs in the struggle against the religious movement in the early 1920s.

Key words: religious movement, party leadership, anti-church politics, educators, special commissions, religious miracles.

Babenko, L. L. (2013). Vzajemodija partijno-radjansjkykh orghaniv ta miscevykh aparativ derzhbezpeky v borotjbi z «relighijnymy chudesamy» (1920-ti - 1940 vi pp.) [Interaction of PartySoviet Bodies and Local Security Authorities in Combating "Religious Miracles" (1920s - 1940s)]. Z arkhiviv VUChK-GhPU-NKVD-KGhB - By the VUChK-GhPU-NKVD-KGhB archives, 1, 327-350. [in Ukrainian].

DAViO - Derzhavnyj arkhiv Vinnycjkoji oblasti. [State Archives of Vinnytsia Region]. [in Ukrainian].

Djakiv, V.M. (2010). Projavy relighijnosti ukrajinciv v umovakh biljshovycjkoji okupaciji pochatku 1920$\mathrm{kh}$ rokiv [Manifestations of Ukrainian religiosity in the conditions of the Bolshevik occupation of the early 1920s]. Visnyk Ljvivsjkogho universytetu. Serija: Filologhija - Bulletin of the University of Lviv. Vyp. 43, 169-180. [in Ukrainian].

Dmytruk, N. (1925). Pro chudesa na Ukrajini roku 1923-gho.[ About miracles in Ukraine in 1923]. Etnoghrafichnyj visnyk - Ethnographic Bulletin, 1, 50-65. [in Ukrainian].

Drovozjuk, S. I. (2005.) Nacionaljno-kuljturne ta dukhovne zhyttja ukrajinsjkogho seljanstva u 20 - 30 kh rr. KhKh stolittja: istorychnyj narys [National-cultural and spiritual life of the Ukrainian peasantry in the 20's - 30's of the XX century: a historical essay]. Vinnycja, 364 s. [in Ukrainian].

Drovozjuk, S.I. (2002) Masovyj relighijnyj rukh v Ukrajini u 20-kh rr. KhKh st.: istorioghrafija problem [Mass Religious Movement in Ukraine in the 1920s: Historiography of the Problem]. Naukovi zapysky Vinnycjkogho derzhavnogho pedaghoghichnogho universytetu imeni Mykhajla Kocjubynsjkogho. Serija: Istorija - - Scientific Papers of the Vinnytsia Mykhailo Kotsyiubynskyi State Pedagogical University. Series: History. Vyp. 4, 247-253. [in Ukrainian].

Ghalamaj, O. M. (2002). Relighijni chudesa na Vinnychchyni. [Religious miracles in Vinnytsia region] Red. P. S. Ghryghorchuk, Vinnychchyna: istorija ta suchasnistj (ss. 50-54). Vinnycja. [in Ukrainian].

Kravchenko, V. (1927) «Psaljmy», shho v 1923 - 24 rr. spivaly prochany pid chas podorozhuvanj do riznykh chudes ["Psalms" which, in the years 1923-24, were sung by pilgrims while traveling to various miracles]. Etnoghrafichnyj visnyk - Ethnographic Bulletin, 4, 71-78. [in Ukrainian].

Olijnyk, M. P. (2013). Projavy chudes ta onovlennja ikon na Podilli v 1923 r. ta borotjba vlady z cym javyshhem [Manifestations of miracles and updating of the icons in the Podillia in 1923 and the struggle of the authorities with this phenomenon]. Osvita, nauka i kuljtura na Podilli, (20), 509-519. [in Ukrainian].

Panasjuk, M. P. (2019). Relighijna tvorchistj podoljan v 1920-kh rr.. [Religious creativity of the peasants in the 1920's.]. Naukovi zapysky Ternopiljsjkogho nacionaljnogho pedaghoghichnogho universytetu imeni Volodymyra Ghnatjuka. Serija: Istorija - Scientific notes of the Ternopil National Pedagogical University named after Volodymyr Hnatyuk. Series: History. Vyp. 2, 123-127. [in Ukrainian].

Pchilka, O. (1925). Ukrajinsjki narodni leghendy ostannjogho chasu [Recent Ukrainian folk legends]. Etnoghrafichnyj visnyk - Ethnographic Bulletin. 1, 41-49. [in Ukrainian].

Stadnyk, O. \& Kuzjminecj, N. (2020). Relighijne zhyttja podiljsjkogho sela u vymirakh radjansjkoji povsjakdennosti 20-kh rr.. KhKh st. [The religious life of the Podilsky village in the dimensions of the Soviet everyday life of the 1920s.]. Naukovi zapysky Vinnycjkogho derzhavnogho pedaghoghichnogho universytetu imeni Mykhajla Kocjubynsjkogho. Serija: Istorija - Scientific Papers of the Vinnytsia Mykhailo Kotsyiubynskyi State Pedagogical University. Series: History. Vyp. 31, 79-87. DOI: https://doi.org/10.31652/2411-2143-2019-31-79-87 [in Ukrainian].

Zavaljnjuk, K., Stecjuk, T. (2007) Relighijni "chudesa" na Podilli (20-ti roky XX stolittja) [Religious "miracles" in Podillia (20s of XX century)]. Red. koleghija: Z. Bilyk, Ja. Dashkevych, L. Moravsjka, Istorija relighij v Ukrajini. Naukovyj shhorichnyk, (409-419). Ljviv: Vydavnyctvo Ljvivsjkogho muzeju istoriji relighiji «Loghos». [in Ukrainian].

Статтю надіслано до редколегії 20.03.2020 р. Статтю рекомендовано до друку 08.05.2020 p. 